\title{
Overinvestment and the Operating Performance of SEO Firms
}

\author{
Fangjian Fu*
}

\begin{abstract}
Prior studies have documented that firms' operating performance deteriorates following seasoned equity offerings (SEOS). This paper proposes and empirically tests the hypothesis that this poor performance is the result of managers' overinvestment. I find that, subsequent to the offering, SEO firms tend to invest more heavily than nonissuing control firms that are in the same industry and have enough financial slack and similar investment opportunities. More importantly, I find a negative correlation between postissue investment and operating performance, controlling for investment opportunities and preissue performance. Overinvestment results in a reduction in asset productivity and is more severe for firms with relatively fewer investment opportunities.
\end{abstract}

Previous studies have documented that firms' operating performance deteriorates following seasoned equity offerings (SEOs). Meanwhile, the postissue stock returns of SEO firms are inordinately low relative to various benchmarks of expected returns. ${ }^{1}$ A popular explanation seems to be managers' timing the market where their decision of SEO is in anticipation of poor future performance. In this paper, I present an overinvestment explanation for poor firm performance after SEOs. Managers' overinvestment of SEO proceeds leads to this poor performance. More specifically, I find that controlling for the differences in industry, investment opportunities, and financial slack, SEO firms still invest more heavily than nonissuing firms and this excess investment is negatively related to postissue operating performance. Further evidence indicates that overinvestment significantly reduces the asset productivity of SEO firms.

Why do managers of SEO firms overinvest after equity offerings? Jensen $(1986,1993)$ argues that managers have various incentives to grow their firm beyond the optimal size. They can enjoy more private benefits by managing a larger firm and their compensation is dependent upon asset growth rather than profitability. Seasoned equity offerings are an effective way to grow firm size. For example, the average SEO proceeds in my sample are $24 \%$ of the issuing firm's market value and they are all cash. The probability of overinvestment increases with free cash flow under managers' control.

This paper is adapted from the first chapter of my doctoral dissertation at the University of Rochester. I am most grateful to my dissertation committee members the late Mike Barclay, John Long, and Cliff Smith for their invaluable guidance and suggestions throughout this project. I also thank Bill Christie (the editor), two anonymous referees, Fred Bereskin, Feng Gao, Iftekhar Hasan, Tim Jenkins, Xuenan Li, Laura Liu, Evgeny Lyandres, Dan Ma, Roni Michaely, Ronald Masulis, David Mauer, Jay Ritter, Dino Silveri, Toni Whited, Wei Yang, Lu Zhang, Yong Zhang, and seminar participants at the University of Rochester, the University of Texas at Dallas, the University of Oxford, Singapore Management University, the 2005 FMA meetings in Chicago, and the 2006 EFA meetings in Philadelphia for helpful comments.

${ }^{*}$ Fangjian Fu is an Assistant Professor of Finance at Singapore Management University's Lee Kong Chian School of Business in Singapore.

${ }^{1}$ See Hansen and Crutchley (1990) and Loughran and Ritter (1997) for findings of deterioration in operating performance, and Spiess and Affleck-Graves (1995), Loughran and Ritter (1995, 2000), and Jegadeesh (2000) for results of poor stock return performance. Ritter (2003) gives a comprehensive review of SEO long-run return studies.

Financial Management $•$ Spring $2010 \cdot$ pages $249-272$ 
From a contracting perspective, firms are not required to disclose the specific use of SEO proceeds prior to the offering. Consequently, managers have discretion over the use of proceeds after the offering. Even though external equity is more costly than internal funding prior to the offering, it is not much different than internal funding once under the manager's control. There is virtually no oversight as in debt financing. Moreover, the manager's percentage of equity ownership often declines after SEOs and shareholders become more diffuse. As a result, the monitoring of large shareholders diminishes and managers have less incentive to abstain from overinvestment. Additionally, equity offerings increase the firm's public float enhancing the manager's ability to raise additional capital through borrowing (Barclay, Fu, and Smith, 2009).

I test the overinvestment hypothesis by examining the postissue corporate investment and its impact on operating performance. Instead of using proxies such as managers' equity ownership to measure agency conflicts, I choose to examine the post-SEO investment directly. Abel and Blanchard (1983) indicate that a firm's optimal investment is a positive function of its expected marginal profit of capital. Consistent with this notion, I develop a simple model to demonstrate that if SEO firms invest to maximize firm value (without agency costs), they should invest less if they anticipate a larger reduction in operating performance. Thus, changes in operating performance are positively related to investment in the cross-section if the investment is optimal. In contrast, overinvestment, by definition, reduces firm value. Changes in operating performance are negatively related to overinvestment if managers overinvest. Therefore, findings of a negative correlation would lend support to the overinvestment hypothesis.

I examine 2,873 SEOs during 1980-1999 and find empirical evidence consistent with the overinvestment hypothesis. These new equity issues increase shares outstanding by $26 \%$ on average. The operating return on assets (ROA), measured by operating cash flow divided by total assets net of cash, decreases by more than $2 \%$ for the median issuer. In the meantime, firms increase investment dramatically. During the first three years subsequent to the offering, SEO firms, on average, invest capital amounting to $67 \%$ of their firm value prior to the offering. When compared to the investment prior to the SEO, the net increase in investment is 1.5 times for the median issuer. The SEO proceeds are used not to retire debt or increase working capital, but to invest. Some firms even issue new debt to increase their investments.

Although this tendency of aggressive investment raises the question whether all the capital is actually invested to increase firm value, it is important to note that most SEO firms are growth firms with many investment opportunities. In order to evaluate the possibility of overinvestment, it is necessary to account for investment opportunities of SEO firms. I match each SEO firm to a nonissuing control firm in the same industry with a similar amount of investment opportunities. The control firm is not financially constrained so that it may fully invest to meet the demand of its investment opportunities. Investment opportunities are measured by the market-to-book ratio of assets prior to the offering. ${ }^{2}$ I find that $67 \%$ of SEO firms in my sample invest more than their control firms. The difference in investments, labeled as abnormal investment, is used to measure the relative likelihood of overinvestment. It is assumed that firms with negative abnormal investment (comprising 33\% of the sample that are issuers investing less than their control firms) are not overinvesting. Firms with positive abnormal investment are more likely involved in overinvestment relative to the previous group.

\footnotetext{
${ }^{2}$ The market-to-book ratio of assets could also capture stock overvaluation. Since SEO stocks are often regarded as overvalued at the time of offering, the use of this ratio could exaggerate the true investment opportunities. Therefore, my estimated abnormal investment of SEO firms tends to be conservative.
} 
I find that postissue operating performance is negatively related to abnormal investment of firms with positive abnormal investment, after controlling for other relevant factors. This evidence lends support to the overinvestment hypothesis. In contrast, among firms with negative abnormal investment (i.e., firms assumed not overinvesting), operating performance is positively related to their investment as predicted by the optimal investment theory. This inverse U-shape correlation between investment and operating performance holds under both regression and decile sorting analyses. Further analyses rule out the possibility that the negative association between investment and operating performance is caused by the lag effect of investment.

One conclusion of my study is that free cash flow problems increase after SEOs. The agency costs of free cash flow are widely documented in the literature. For example, Jensen (1986) points out that the increases in oil prices since 1973 generated large increases in free cash flow in the petroleum industry. Managers did not pay out the excess resources to shareholders. Instead, the industry continued to spend heavily on exploration and development activities even though average returns were below the cost of capital. Lang, Stulz, and Walkling (1991) suggest that some tender offer mergers and acquisitions are driven by the free cash flow of the bidder firm. Blanchard, López-de-Silanes, and Shleifer (1994) suggest that managerial behavior after a cash windfall in the form of a successful or settled lawsuit is explained by the agency model. Lang, Poulsen, and Stulz (1994) imply that the agency costs of free cash flow increase after asset sales. Bates (2005) provides explicit evidence confirming that firms retaining the cash proceeds from large asset sales systematically overinvest relative to an industry benchmark. Nohel and Tarhan (1998) find that operating performance improves after firms buy back stocks through tender offers. They suggest that this is because stock repurchase firms pay out free cash flow and employ assets more efficiently. Equity offerings are often regarded as the opposite of stock repurchases bringing in a large amount of cash to the issuer. It is likely than that free cash flow problems increase after the equity offerings.

This study, however, is not the first to notice the increase in free cash flow problems due to equity issues. Jung, Kim, and Stulz (1996) suggest that increased free cash flow problems explain the negative stock price reaction to SEO announcements. Lee (1997) finds that long-run stock returns of secondary offerings through which existing shareholders sell large amounts of shares to the public do not underperform their benchmarks, while SEOs experience significantly lower returns relative to their benchmarks. He suggests that the evidence can be explained by increased free cash flow problems after SEOs. I determine that poor operating performance after SEOs are also explained by increased free cash flow problems.

My paper is closely related to two other studies that document a significant correlation between investment and stock return underperformance. Loughran and Ritter (1997) find firms that rapidly increase capital expenditures have lower subsequent stock returns than other firms. Lyandres, Sun, and Zhang (2008) argue that an investment factor, long in low-investment stocks and short in high-investment stocks, helps to explain new issues puzzles. Adding this dynamic into standard factor regressions reduces the SEO stock return underperformance by about $75 \%$. I confirm that investment also explains the operating underperformance of SEO firms.

The remainder of this paper is organized as follows. In Section I, I describe the SEO data. I examine operating performance in Section II. Section III considers the postissue uses of proceeds. In Section IV, I present a simple model to illustrate the relationship between postissue investment and operating performance without and with overinvestment, respectively, and then investigate the correlation empirically. A short conclusion follows in Section V. 


\section{The Data of Seasoned Equity Offerings}

The sample selection starts with all seasoned equity offerings in the years 1980-1999 (inclusive) as reported in the Securities Data Corporation electronic database. I choose 1980 as the beginning year as the operating performance of many small firms is not reported in Compustat prior to 1980. SEO issuers are relatively small in size, so results based on the SEOs of large firms could be biased. The sample period ends at 1999 to allow for at least five years of data of postissue operating performance. I impose several filters:

1. The SEO stock must be listed on CRSP's file of monthly stock returns at the time of the offering. This criterion ensures that SEO stocks are traded on the NYSE, AMEX, or NASDAQ.

2. The issue must involve common stock only (CUSIP issue type check digit 10 or 11). This criterion ensures a focus on operating companies. Closed-end funds, real estate investment trusts, and American Depository Receipts are excluded.

3. The SEO is not made by a utility (SIC codes 4910-4949) or a financial institution (SIC codes 6000-6999). Public utility firms have less of an information asymmetry problem (Smith, 1986). Strict regulations make managers' investment decisions less discretionary relative to other industrial firms. Consequently, overinvestment is also less of a concern in utility firms. More importantly, I do not find postissue poor performance for utility firms. Banks may involuntarily issue new equity to meet regulatory capital requirements. An additional reason for the exclusion of financial institutions is that their extremely high leverage ratios distort many of the accounting ratios.

4. The firm has not conducted an SEO in the previous five years. ${ }^{3}$

5. The issuing firm's book value of assets in the fiscal year prior to the offering is available in the CRSP- and Compustat-merged database.

6. If it is a combined offering, its primary shares consist of more than $50 \%$ of all the offering shares.

The whole procedure produces a sample of 2,873 SEOs, which constitutes the basis for most of the empirical investigations in this paper.

Overinvestment is defined to be excess investment after exhausting positive NPV projects. Therefore, the magnitude of SEO proceeds has to be large enough to generate material impact on firm performance. I evaluate this value by comparing SEO proceeds to the issuing firm's value. ${ }^{4}$ Table I confirms that the average cash inflow to the issuing firm is indeed substantial. The mean SEO proceeds $(P)$ are about $24 \%$ of the issuer's market value of assets $(V)$ at the end of the fiscal year before the offering. The mean ratio of new to old shares is 0.26 , suggesting that average equity size increases more than a quarter after the offering. SEO firms have many investment opportunities as reflected by their high market-to-book ratio of assets $(V / A)$. However, it is still possible that the huge amount of cash proceeds exceed the issuer's optimal investment needs.

\footnotetext{
${ }^{3}$ Once a firm did an SEO, that firm cannot reenter the sample until five years from the issue date has passed. This practice follows Healy and Palepu (1990) and Loughran and Ritter (1997). They argue that the purpose is to reduce the dependence of statistical tests. The results remain the same if these repeated SEOs are included.

${ }^{4}$ I define SEO proceeds to be the cash inflow that goes to the issuing firm. In primary equity offerings, the SEO proceeds equal total offering proceeds, while for combined offerings, the SEO proceeds are less than the total offering proceeds. This difference goes to the selling shareholders.
} 


\section{Table I. Summary Statistics of Seasoned Equity Offerings (SEOs)}

The SEO sample is obtained from the Securities Data Corporation. It consists of 2,873 seasoned equity offerings during the period 1980-1999. The following criteria are applied to select the sample: 1) the stock is listed on the CRSP monthly stock file at the time of the offering, 2) the issue involves common stock only, 3) the company is not a regulated utility (SIC codes 4910-4949) or a financial institution (SIC codes 6000-6999), 4) the firm has not conducted an SEO in the previous five years, 5) the book value of assets of SEO firms must be present on the CRSP- and Compustat-merged database, and 6) if it is a combined offering, its primary shares consist of more than $50 \%$ of all the offering shares. NS/OS represents the ratio of new shares to existing shares outstanding. The SEO proceeds $(P)$ are the cash inflow that goes to the issuing firm as measured by the product of new offering shares and the offer price. $A$ is the book value of assets in the fiscal year prior to the offering (Compustat data item 6 ). $V$ stands for the market value of assets as measured by book value of asset minus book value of equity plus market value of equity (Compustat data6 - data60 + data $199 *$ data25). $B E$ and $M E$, respectively, represent the book value and the market value of equity in the fiscal year prior to the offering. Ind $A$ represents the industry median book value of assets where industry is classified by two-digit SIC codes.

\begin{tabular}{lcccccc}
\hline \hline Variable & Mean & Median & Quartile 1 & Quartile 3 & SD & N \\
\hline$N S / O S$ & 0.26 & 0.20 & 0.13 & 0.29 & 0.48 & 2,821 \\
$P / V$ & 0.24 & 0.17 & 0.09 & 0.28 & 0.35 & 2,496 \\
$P / A$ & 1.06 & 0.41 & 0.17 & 0.93 & 3.91 & 2,873 \\
$V / A$ & 2.71 & 1.79 & 1.25 & 3.05 & 2.54 & 2,496 \\
$B E / M E$ & 0.44 & 0.34 & 0.19 & 0.57 & 0.37 & 2,496 \\
A/Ind_A & 8.31 & 1.15 & 0.43 & 3.51 & 28.99 & 2,858 \\
\hline \hline
\end{tabular}

SEO firms are not required to disclose the specific use of proceeds in the prospectus that they file to the SEC prior to the offering. Most issuers only vaguely claim that the proceeds are for "general corporate purposes." Therefore, external capital is no different than internal capital once it is under the manager's control. Given the enormous amount of cash inflows to the firm and the lack of contracting on the use of proceeds, I hypothesize that free cash flow increases after the offering, at least for some SEO firms. In this paper, I examine whether some SEO firms overinvest and whether their operating performance is negatively affected after the offering.

\section{The Operating Performance Surrounding SEOs}

This section examines the operating performance of SEO firms. Due to the skewness of accounting ratios, it is typical to report median values in studies examining operating performance. In Table II, I report the median operating-income-to-assets ratio, earnings per share (EPS), ROA, cash flow ROA, asset turnover, and operating margin on sales for the sample of SEO firms. The horizon starts from the third fiscal year before the offering and ends at the fifth fiscal year after the offering.

As suggested by Barber and Lyon (1996), I use the operating-income-to-assets ratio (operating ROA hereafter) as the primary measure of operating performance in this study. ${ }^{5}$ It is estimated as operating income before depreciation (Compustat data item 13) divided by the average of the beginning and ending period cash-adjusted assets [total assets (data item 6) minus cash

\footnotetext{
${ }^{5}$ This measure is frequently used in studies of operating performance (Healy, Palepu, and Ruback, 1992; Loughran and Ritter, 1997; Nohel and Tarhan, 1998). Relative to earnings (net income), operating income before depreciation is less affected by managerial discretions and, as such, measures true operating performance better.
} 
Table II. Median Operating Performance Surrounding Statistics of Seasoned Equity Offerings (SEOs)

This table presents the median operating surrounding SEOs. The data are obtained from the CRSP/ Compustat-merged database. The horizon covers from the third year before the offering to the fifth year after the offering. The variables are defined as follows: operating returns on cash-adjusted assets (Operating ROA) is measured as data13/average(data6 - data1); earnings per share (EPS) is data58; return on assets (ROA) is measured as data18/average(data6); cash flow ROA is measured as (data13 $+\Delta$ data2 $+\Delta$ data3 $-\Delta$ data $70-\Delta$ data $72+\Delta$ data68)/average(data6 - data1). The function of average () is to take the average of the beginning and ending period values. The operating ROA is decomposed into two variables so that operating ROA equals the product of asset turnover and operating margin on sales. Asset turnover is computed as data12/average(data 6 - data1) and operating margin on sales is computed as data13/data12. All variables except EPS are in percentages. Year 0 is the fiscal year of the offering. $N$ is the number of issuing firms whose operating ROA is available.

\begin{tabular}{lccccccc}
\hline \hline Year & $\begin{array}{c}\text { Operating } \\
\text { ROA }\end{array}$ & $\begin{array}{c}\text { EPS } \\
\mathbf{( \$ )}\end{array}$ & ROA & $\begin{array}{c}\text { Cash Flow } \\
\text { ROA }\end{array}$ & $\begin{array}{c}\text { Asset } \\
\text { Turnover }\end{array}$ & $\begin{array}{c}\text { Operating Margin } \\
\text { on Sales }\end{array}$ & $\mathbf{N}$ \\
\hline-3 & 15.03 & 0.39 & 4.30 & 17.49 & 151.04 & 9.64 & 1,628 \\
-2 & 15.09 & 0.36 & 4.33 & 18.68 & 150.02 & 9.96 & 2,014 \\
-1 & 16.44 & 0.42 & 4.81 & 20.85 & 151.03 & 10.58 & 2,504 \\
0 & 16.67 & 0.57 & 5.28 & 23.38 & 144.44 & 11.39 & 2,826 \\
+1 & 14.18 & 0.45 & 3.89 & 18.77 & 128.63 & 10.27 & 2,720 \\
+2 & 12.03 & 0.32 & 2.57 & 14.39 & 122.35 & 9.05 & 2,563 \\
+3 & 11.81 & 0.25 & 2.01 & 13.25 & 120.37 & 9.12 & 2,379 \\
+4 & 11.87 & 0.25 & 2.03 & 12.93 & 118.17 & 8.98 & 2,207 \\
+5 & 11.26 & 0.18 & 1.62 & 11.77 & 119.10 & 8.62 & 2,045 \\
\hline \hline
\end{tabular}

and marketable securities (data item 1)]. The numerator, operating income before depreciation, is commonly referred to as EBITDA (earnings before interest, taxes, depreciation, and amortization). Since many issuers may temporarily park some of the SEO proceeds in the form of cash and marketable securities before investing in operating assets, I subtract cash and marketable securities from total assets for the denominator. This portion of assets is not supposed to generate income at the same rate as the firm's operating assets do.

I decompose operating ROA into two components: 1) asset turnover and 2) operating margin on sales. Asset turnover, computed as sales (data item 12) divided by the average of the beginning and ending period cash-adjusted assets, measures the sales dollars generated from each dollar of investment in assets. This, in effect, measures the productivity of operating assets. Operating margin on sales is computed as EBITDA divided by sales measuring the operating income generated by per sales dollar. The degree of competition has a significant impact on this variable. Intensive competition reduces the operating margin on sales. Operating ROA equals the product of asset turnover and operating margin on sales as follows:

$$
\text { Operating ROA }=\text { Asset Turnover } * \text { Operating Margin } \text {. }
$$

The decomposition helps to identify the underlying reasons for changes in operating ROA. For example, if managers invest capital in negative NPV projects, it reduces asset productivity but does not have much direct impact on the operating margin on sales. Thus, overinvestment should decrease operating performance by reducing asset turnover. 
In addition to the operating ROA, I examine three alternative measures of operating performance: 1) EPS, 2) ROA, and 3) cash flow ROA. The Compustat data items for these measures are described in Table II. The use of cash flow ROA helps to overcome the potential earnings manipulation problem documented in some studies. ${ }^{6}$ However, Barber and Lyon (1996) point out that among all the performance measures they examined, the cash flow ROA yields the least powerful test statistics. Moreover, recent studies such as Shivakumar (2000), Brous, Datar, and Kini (2001), and Denis and Sarin (2001) cast doubt on the effectiveness of earnings management around SEOs. Trading off benefits and costs, I choose to use operating ROA as the primary measure of operating performance and use other variables to check result robustness.

The numbers presented in Table II suggest a clear trend. The operating performance measured by all four variables increases before the offering, peaks at the offering, and drops substantially after the offering. For the median issuer, operating ROA is $15.03 \%$ three years before the offering, peaks at $16.67 \%$ in the year of the offering, and falls to $11.26 \%$ five years after the offering. EPS for the median SEO starts at $\$ 0.39$ three years prior to the offering, reaches $\$ 0.57$ in the offering year, and then drops to $\$ 0.18$ within five years of the offering. The median ROA begins at $4.30 \%$ three years before the offering, reaches $5.28 \%$ in the offering year, and drops to $1.62 \%$ five years after the offering. Similarly, the median cash flow ROA peaks at $23.38 \%$ in the offering year and falls to $11.77 \%$ after five years. The time-series patterns of operating performance are very similar to the findings of Loughran and Ritter (1997). Their sample consisted of 1,338 SEOs from 1979 to 1989 . My sample size is twice as large due to the longer sample period.

When I refer to changes in operating performance after the SEO, I am comparing the performance in the postissue years to the performance in the years prior to the SEO. The performance in the offering year is excluded as it is hard to differentiate which part of the measure is before and which part is after the offering. I define the three fiscal years before the offering to be the preissue years, and the five fiscal years after the offering to be the postissue years.

Two different methods are used to estimate the change in operating performance. The first method is straightforward. For each SEO firm, I estimate the median (and mean) performance in the preissue years and the postissue years, respectively, and define their difference as the postissue performance change. This method implicitly assumes the high persistence of operating performance. Therefore, the issuer's own preissue performance is regarded as the benchmark for the expected postissue performance. In Panel A of Table III, I report the median change in operating performance across all the SEO firms. Medians are evaluated by the Wilcoxon signed-rank test. All four measures of operating performance decline significantly after the offering ( $p$-value less than 0.001 ). Among them, the median operating ROA decreases by $2.87 \%$. The decomposition of operating ROA demonstrates that the decrease is largely attributable to a significant drop in asset turnover (a median drop of $21.71 \%$ ). I do not find a significant change in the operating margin on sales. Note that overinvestment leads to inefficient deployment of assets and reduces asset turnover. The severe drop in asset turnover hints that managers' overinvestment of SEO proceeds may be a reason for the deterioration of operating performance.

I also estimate the change in operating performance by an alternative method. In choosing a model of expected operating performance, Barber and Lyon (1996) suggest matching sample firms to control firms based on firm size and preevent performance as this method yields wellspecified test statistics in most scenarios. The matching of preevent performance is important to control the mean-reverting property of accounting-based measures. Regarding the choice of a statistical test, they recommend the nonparametric Wilcoxon test statistics. To implement this

\footnotetext{
${ }^{6}$ See, for example, Teoh, Welch, and Wong (1998) and Rangan (1998). These studies find that managers of issuing firms tend to manage earnings upward by boosting up accounting accruals in the year before and the year of the offering.
} 
Table III. Change in Operating Performance after Seasoned Equity Offerings (SEOs)

This table presents the median change in operating performance, estimated using two different methods, surrounding SEOs. The variables are defined in Table II. Panel A presents the median difference in raw operating performance between the post- and preissue years. The preissue years are defined to be the three years before the offering, and the postissue years are the five years after the offering. For each SEO firm, I compute the median values of operating performance in the preissue years and in the postissue years, respectively. I then calculate their difference between pre- and postissue performance. The reported numbers are the median difference across firms. Panel B presents the median difference in abnormal operating performance between the post- and preissue years. The method of abnormal performance estimation follows Barber and Lyon (1996). Sample SEO firms are matched with control firms on the basis of the book value of assets at the end of the offering year and the operating ROA in the fiscal year before the offering. The following procedure uses identical to as that used to compute the numbers in Panel A. If there are missing data, the median is computed using data for the remaining years. The results are evaluated using the Wilcoxon signed-rank test.

Panel A. Median Change in Raw Operating Performance and the Wilcoxon Test

\begin{tabular}{cccccccr}
\hline \hline $\begin{array}{c}\text { Operating } \\
\text { ROA }\end{array}$ & $\begin{array}{c}\text { EPS } \\
(\$)\end{array}$ & ROA & $\begin{array}{c}\text { Cash Flow } \\
\text { ROA }\end{array}$ & $\begin{array}{c}\text { Asset } \\
\text { Turnover }\end{array}$ & $\begin{array}{c}\text { Operating } \\
\text { Margin } \\
\text { on Sales }\end{array}$ & $\mathbf{N}$ \\
\hline Median & $-2.87^{* * *}$ & $-0.09^{* * *}$ & $-1.88^{* * *}$ & $-8.62^{* * *}$ & $-21.71^{* * *}$ & 0.00 & 2,382 \\
\hline \hline
\end{tabular}

Panel B. Median Change in Abnormal Operating Performance and the Wilcoxon Test

\begin{tabular}{ccccc}
\hline \hline & Operating ROA & Asset Turnover & Operating Margin on Sales & $\boldsymbol{N}$ \\
\hline Median & $-2.23^{* * *}$ & $-15.26^{* * *}$ & 0.00 & 2,312 \\
\hline
\end{tabular}

${ }^{* * *}$ Significant at the 0.01 level.

method, I first limit the universe of control firms to firms that are traded on the AMEX, NYSE, or NASDAQ and have not issued equity in the previous five years. Thus, control firms are nonissuers. Second, for each SEO firm, I require its control firms to have a book value of assets within $50 \%$ to $150 \%$ of the issuing firm at the end of the offering year (Year 0). Third, I require that the control firms' operating ROA in the fiscal year prior to the offering (Year -1) be within $90 \%$ to $110 \%$ of the SEO firm. Last, I select the control firm that has the closest match on operating ROA. ${ }^{7}$ The operating performance of the control firm is regarded as the benchmark of expected performance for the SEO firm. I calculate the difference as the abnormal operating performance of the issuer in each year.

The next steps are similar to the first method. For each SEO firm, I compute the difference between the median abnormal performance during the five post-SEO years and the median abnormal performance during the three pre-SEO years. These results are reported in Panel B of Table III. The median (mean) difference in operating ROA across SEO firms is $-2.23 \%$ $(-2.68 \%)$ and the drop is statistically significant at $1 \%$. An examination of the two components again indicates that this drop is mainly due to the decrease in asset turnover. The median (mean) change in asset turnover is $-15.26 \%(-22.27 \%)$ after equity offerings, while the change in the

\footnotetext{
${ }^{7}$ About 300 SEOs do not find size- and performance-matched control firms. These SEOs are excluded from the following analysis. I do not relax matching criteria to avoid potentially large measurement errors.
} 
operating margin on sales is not different from zero. In short, different methods yield consistent results; the operating performance of SEO firms drops significantly after the offering and that drop is largely induced by the reduction in asset productivity.

\section{The Use of SEO Proceeds}

An SEO brings in a large amount of cash inflow to the issuer. After the SEO, the issuer's operating performance reduces significantly. If I look into details, each unit of operating assets does not generate the same amount of sales revenue as before. A natural question to ask is what these firms do with this large amount of capital. Do managers use the money to maximize firm value?

I hypothesize four main uses of SEO proceeds: 1) investing, 2) retiring debt, 3) increasing working capital, or 4) hoarding cash. Table IV presents the median leverage ratio, change in debt, ratio of working capital to operating income, change in working capital, change in cash and marketable securities, and investment from three years before through five years after the offering. Book leverage is fairly stable prior to the SEO. The median is around $25 \%$. Since stock prices of SEO firms increase before the offering, the market leverage ratio decreases. Leverage decreases significantly in the offering year (Year 0) as SEOs increase the equity portion of the firm. The decrease, however, does not last longer than three years. Leverage ratios revert to the preissue level at the end of the third year after the SEO. This quick reversal of the leverage ratio suggests that the primary use SEO proceeds is not to retire debt. This is confirmed by the mean change in debt reported in the third column. The numbers are all positive in the years after the SEO and the amounts issued after SEOs are no less than those of the preissue years. I calculate the cumulative change in debt from Year 0 to Year 5 for each SEO firm and find that over 70\% of SEO firms increase debt during this period and fewer than $30 \%$ of firms either maintain their debt level or retire debt after the SEO. Instead of retiring debt, SEO issuers typically issue a substantial amount of debt shortly after SEOs. ${ }^{8}$

SEO firms may use the proceeds to increase working capital. I compute working capital as the difference between current assets net of cash and marketable securities and current liabilities net of short-term debt. The numbers are deflated by operating income before depreciation (EBITDA). This ratio indicates a slow decrease after SEOs. Issuers, in fact, maintain less working capital per unit of income. The next column reports the net dollar change in working capital. I observe a more than $100 \%$ increase in Years 0 and 1 relative to Year -1 , but the magnitude is not great relative to the SEO proceeds. Moreover, the net changes afterward are similar to the pre-SEO years. Combining the evidence, I argue that an increase in working capital does not absorb much of the SEO proceeds.

Note that my definition of working capital excludes cash and marketable securities. Issuers may place proceeds temporarily in cash and marketable securities after offerings. The dollar change in cash and marketable securities increases before the offering, but in small quantities until the year of the offering where the median change jumps to $\$ 5.81$ million. Issuers then reduce the holding of cash and marketable securities during the three years subsequent to the SEOs. SEO firms may store a part of their proceeds in cash and marketable securities and then spend it in subsequent years.

\footnotetext{
${ }^{8}$ The median changes in debt are zeros or close to zero in each of the five post-SEO years. This, however, does not suggest that half of the firms add no debt in the postissue years. This is because debt issuances are often in lump sum amounts and the majority of firms usually do not change their debt amount in a given year.
} 


\section{Table IV. Use of Statistics of Seasoned Equity Offering (SEO) Proceeds}

This table reports the median leverage, working capital, change in cash, and investment within the nine-year window of SEOs including three years before, the year of, and five years after the SEO. The variables are defined as follows:

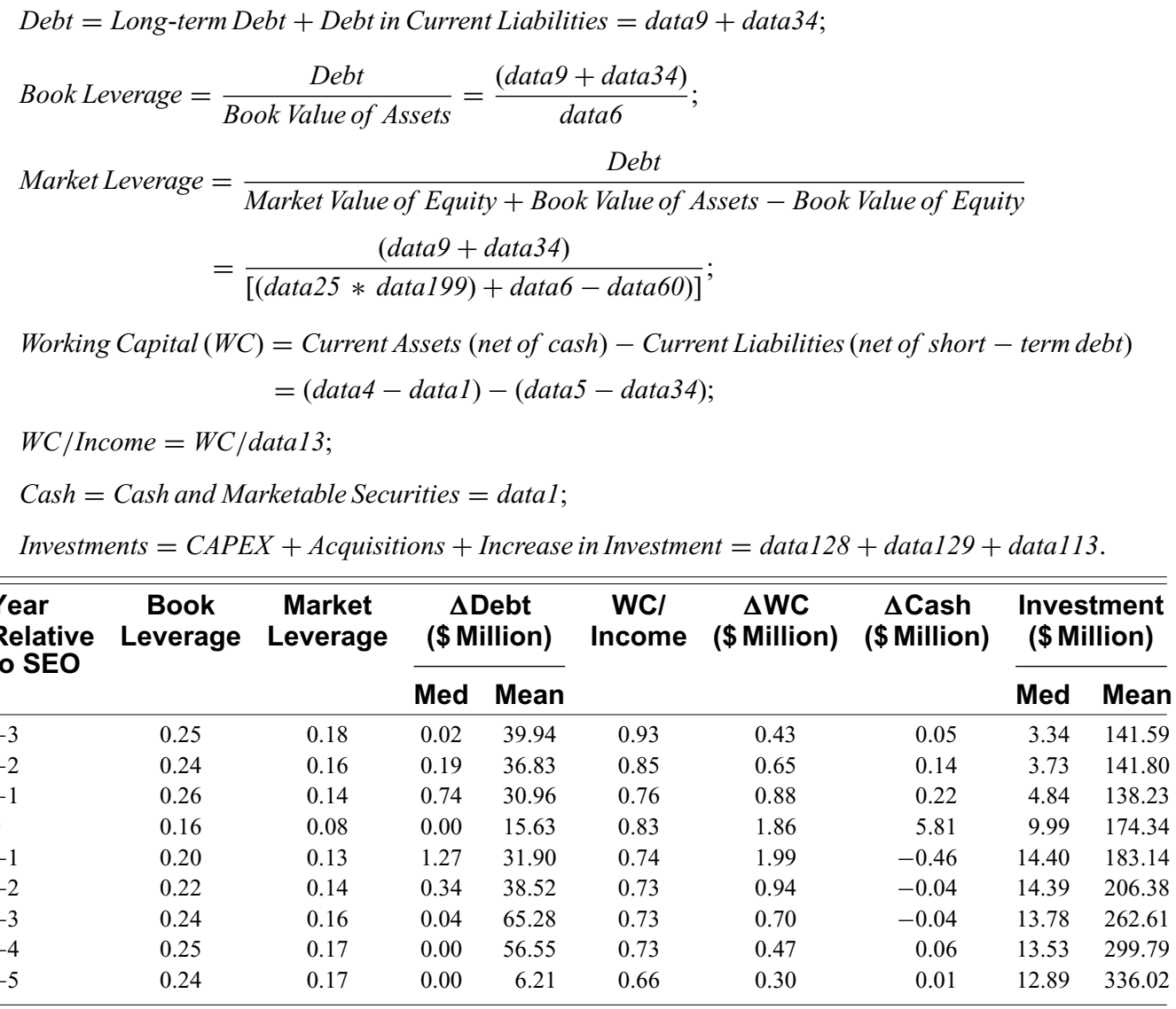

The last column presents the median annual investment during the nine-year window. Investment includes capital expenditures (Compustat data item 128), acquisition expenses (data item 129), and increases in investments (data item 113). Note that investment is a flow variable like net changes in debt, working capital, and cash in previous columns. The level of new investment is fairly stable prior to the offering. The median magnitude is about $\$ 4$ million. However, it soars to $\$ 10$ million at Year 0 and even further to $\$ 14$ million during subsequent years. The postissue increase in investment is substantial and persistent. The mean investment displays a similar time-series pattern but in much higher values since investment usually occurs in lump sum amounts.

To summarize, the dominant use of SEO proceeds is to expand investment primarily in capital expenditures and acquisition expenses. Retiring debt is not a likely major use of these proceeds. The effects of SEOs on leverage are transient. Issuing firms issue substantial amounts of debt to move leverage back to the preissue level. The increase in working capital is small in size and not 
significant in the long run. Firms tend to hoard some proceeds in cash accounts. This part of the proceeds may finally be used to expand investment.

\section{Postissue Investment and Its Impact on Operating Performance}

This section examines the postissue investment of SEO firms and its impact on firm performance. I first develop a simple model. The model predicts that if firms invest optimally, the change in operating performance is positively related to the investment. However, if firms overinvest, the correlation between investment and change in operating performance is negative.

\section{A. A Simple Model of Investment and Operating Performance}

The model has two periods: 1) the period prior to the equity offering and 2) the period after the offering. For simplicity, I assume that firms pay all the operating profits out to shareholders and are then liquidated at the end of the second period. Before the offering, the issuer has assets, $A_{0}$. The existing assets generate operating profit, $E_{0}$, in each of these two periods. Therefore, the ROA before the offering is $\frac{E_{0}}{A_{0}}$. Issuing firms raise capital through the SEO and make investment decisions. Investment $(I)$ takes places in the period after the offering and increases the firm's assets. For simplicity, I assume that the discount rate of assets is zero. Thus, the assets involve as follows:

$$
A_{1}=A_{0}+I
$$

The investment generates profit in the period after the offering. The profit is positive if capital is invested in positive NPV projects and could be negative if capital is overinvested. Overinvestment is defined as the investment in value-destroying projects. Therefore, the net profit is determined by the investment that increases firm value and overinvestment. I specify the total investment as

$$
I=I^{*}+\varepsilon
$$

where $I^{*}$ represents the investment that increases firm value and $\varepsilon$ represents overinvestment. The net profit, $\Pi(I)=\Pi\left(I^{*}, \varepsilon\right)$, is increasing in $I^{*}$ and decreasing in $\varepsilon$. The operating income generated in the second period, denoted as $E_{1}$, is the sum of $E_{0}$ and $\Pi(I)$. The ROA in this period is $\frac{E_{1}}{A_{1}}=\frac{E_{0}+\Pi(I)}{A_{0}+I}$.

I first assume that SEO firms invest optimally to maximize firm value (i.e., they do not overinvest). $\varepsilon=0$, and $I=I^{*}$. The literature of investment suggests that optimally, a firm should invest until the marginal cost of investing equals the shadow value of installed capital. The optimal investment is essentially determined by the firm's investment opportunities (Tobin, 1969; Abel, 1983; Abel and Blanchard, 1983). In Figure 1, I illustrate the optimal investment of a firm. The horizontal axis represents the firm's investment deflated by its existing assets $\left(I / A_{0}\right)$ and the vertical axis is the marginal $q$, which measures the marginal return on investment. The marginal $q$ is decreasing in investment, as described by the law of diminishing marginal benefit. Mathematically, the derivative of marginal $q$ with respect to investment is negative (i.e., the slope of marginal $q$ is negative). For simplicity, I approximate the marginal $q$ curve by a downward sloping line. However, the linearity is not required. The results to be presented hold under a convex or concave marginal $q$ curve as long as marginal $q$ is decreasing in investment. For simplicity, I assume the marginal cost of investment to be one. It is clear that the marginal profit is decreasing in investment and that firms should invest until the marginal $q$ reaches the 


\section{Figure 1. The Optimal Investment of a Firm}

This figure illustrates the optimal investment of a firm. The horizontal axis represents the firm's investment deflated by its existing assets $\left(I / A_{0}\right)$ and the vertical axis is the marginal $q$, which measures the marginal return on investment. The marginal $q$ is decreasing in investment as described by the law of diminishing marginal benefit. This is demonstrated in the figure by the negative slope of the marginal $q$ curve. The marginal cost of investment is assumed to be one. $I^{*} / A_{0}$ denotes the optimal investment deflated by assets with respect to the marginal $q$ at point $\mathrm{B}$. The shaded area stands for the net profits generated by the optimal investment.

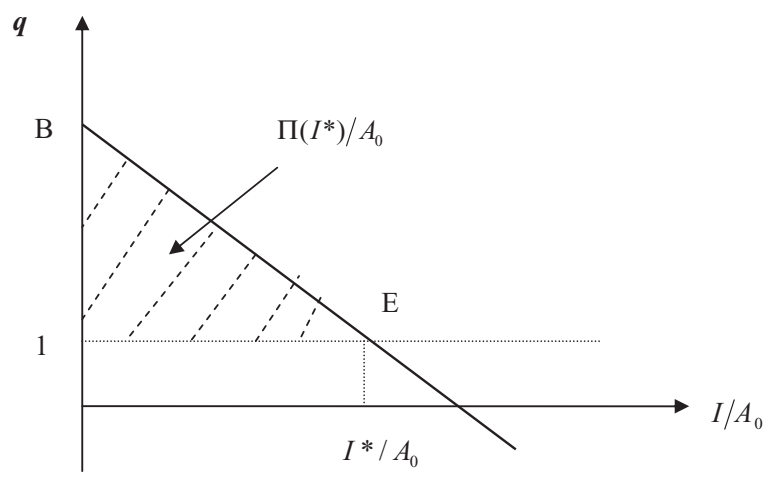

marginal cost of investment, which is one. Assuming an increasing and convex adjustment cost of investment does not change the basic implication. This would only make the decrease of net profit in investment faster. If the issuing firm's marginal $q$ is at point B in the figure, ideally, the firm should invest until its marginal $q$ reaches point $\mathrm{E}$, where $q=1$. The optimal investment deflated by assets is denoted by $I^{*} / A_{0}$, and the net profits generated by the optimal investment is the shaded area, which is $\Pi\left(I^{*}\right) / A_{0}$. The average returns on the optimal investment is $\Pi\left(I^{*}\right) / I^{*}$.

Suppose now that the marginal $q$ at the time of the SEO is higher than $\mathrm{B}$. This $q$ line shifts upward. The firm has a larger set of investment opportunities and should optimally invest more. The net profit measured by the shaded area in Figure 1 also increases. More importantly, the decreasing property of marginal profit in investment implies that the increase in net profit is convex in optimal investment. As a result, $\Pi\left(I^{*}\right) / I^{*}$, the average return on optimal investment, is also increasing in optimal investment. In short, investment opportunities at the time of the SEO determine the optimal investment, net profit, as well as the average return on optimal investment after the offering.

The variable of interests, the change in operating performance after SEOs, can be derived as follows:

$$
\begin{aligned}
\triangle R O A & =\frac{E_{1}}{A_{1}}-\frac{E_{0}}{A_{0}} \\
& =\frac{E_{0}+\Pi\left(I^{*}\right)}{A_{0}+I^{*}}-\frac{E_{0}}{A_{0}} \\
& =\frac{\frac{\Pi\left(I^{*}\right)}{I^{*}}-\frac{E_{0}}{A_{0}}}{\frac{A_{0}}{I^{*}}+1} .
\end{aligned}
$$


The first term in the numerator, the average return on investment, $\frac{\Pi\left(I^{*}\right)}{I^{*}}$, is increasing in the optimal investment, $\frac{I^{*}}{A_{0}}$. The second term, $\frac{E_{0}}{A_{0}}$, is the operating ROA before the offering. The first term in the denominator, $\frac{A_{0}}{I^{*}}$, is the reciprocal of $\frac{I^{*}}{A_{0}}$ and it is decreasing in $\frac{I^{*}}{A_{0}}$. Since the numerator is increasing and the denominator is decreasing in the optimal investment, the change in operating ROA $(\triangle R O A)$ is positively related to $\frac{I^{*}}{A_{0}}$. Consequently, I have the following proposition:

PROPOSITION 1: Assuming that firms invest to maximize firm value and that the net profit function is concave in investment and convex and increasing in optimal investment, the change in operating performance is positively related to optimal investment.

The model above predicts a monotonically positive correlation between optimal investment and the change in operating performance. However, it does not consider the potential agency conflicts between managers and shareholders. Prior studies and anecdotal evidence suggest that managers have incentives to invest capital in value-decreasing projects in pursuit of their own benefits; therefore, $\varepsilon>0$ in Equation (3). Overinvestment, by definition, incurs losses and affects the operating performance negatively. This is shown in the following equation:

$$
\triangle R O A=\frac{E_{1}}{A_{1}}-\frac{E_{0}}{A_{0}}=\frac{E_{0}+\Pi\left(I^{*}+\varepsilon\right)}{A_{0}+\left(I^{*}+\varepsilon\right)}-\frac{E_{0}}{A_{0}} .
$$

The numerator of the first term is decreasing in $\varepsilon$ and the denominator is increasing in $\varepsilon$ for any fixed $I^{*}$; therefore, the ROA after the offering is decreasing in $\varepsilon$. I present the following proposition:

PROPOSITION 2: If SEO firms overinvest, the overinvestment reduces a firm's operating performance. Controlling for the optimal investment, the change in operating performance is negatively related to overinvestment.

In short, if SEO firms do not overinvest, I expect to observe a positive correlation between change in operating ROA and investment. Investment opportunities are the exogenous factor that determines both optimal investment and future operating performance. However, if SEO firms overinvest, this overinvestment reduces firm value and operating performance. Findings of a negative association between investment and operating performance would lend support to the overinvestment hypothesis.

\section{B. Postissue Investment of SEO Firms}

For each SEO firm, I compute the post-SEO annual investment as the mean investment from Year 0 to Year 2 and deflate it by the firm value at the end of the fiscal year prior to the offering. I also estimate the net investment growth rate $(\mathrm{d} I / I)$ as the difference between the postissue and preissue investments scaled by the preissue investment, which is the investment at fiscal Year -1. Panel A of Table V presents these results. The median postissue investment deflated by the book value of assets $(I / A)$ is $24.73 \%$. The median issuer increases book assets by $74 \%$ through investment from Year 0 to Year 2. The median value of investment deflated by market value $(I / V)$ is $11.80 \%$. Thus, issuers' investment after the SEO is fairly high relative to their existing assets. The mean values are higher than the medians. This positive skewness indicates that some firms invest very aggressively. The median net investment growth rate is above $100 \%$, implying that the majority of SEO firms double and even triple their investment after the offering. 


\section{Table V. Postissue Investment of Seasoned Equity Offering (SEO) Firms}

This table reports summary statistics of the postissue investment of SEO firms. Investment $(I)$ is the sum of capital expenditures (Compustat data item 128), acquisition expenses (data item 129), and increase in investments (data item 113). I compute the mean annual investment during Year 0 through Year 2 and deflate it by the book value of assets $(I / A)$ or the market value of the firm $(I / V)$ in the preissue year. $\mathrm{d} I / I$ stands for the net investment growth calculated by dividing the difference between the postissue and preissue investments by the preissue investment. Panel A reports the raw investment. Panel B presents the abnormal investment relative to a control firm that has the closest market-to-book value of assets $(V / A)$ to the SEO firm and is not financially constrained (the matching firm has an interest coverage ratio greater than three in magnitude or above the bottom quartile in the industry of the same two-digit SIC code, whichever is larger).

\begin{tabular}{lcrrrr}
\hline \hline Variables & $\boldsymbol{N}$ & Mean & Median & Quartile 1 & Quartile 3 \\
\hline \hline \multicolumn{5}{c}{ Panel A. Raw Investment } \\
\hline \hline$I / A$ & 2,840 & 67.98 & 24.73 & 11.70 & 57.92 \\
$I / V$ & 22.39 & 11.80 & 5.69 & 24.70 \\
$\mathrm{~d} I / I$ & 1269.55 & 145.35 & 24.25 & 462.57 \\
\hline \hline \multicolumn{5}{c}{ Panel B. Benchmark-Adjusted Investment } \\
\hline \hline$I / A$ & 2,804 & 30.30 & 8.24 & -3.19 & 31.83 \\
$I / V$ & 12.11 & 4.07 & -1.99 & 15.34 \\
$\mathrm{~d} I / I$ & 2,438 & 665.58 & 59.01 & -76.79 & 296.27 \\
\hline \hline
\end{tabular}

The model in the previous section suggests that the cross-sectional relationship between investment and change in ROA hinges critically on the likelihood of overinvestment. Change in ROA is positively related to investment if firms invest optimally. Controlling for the optimal investment could be negatively related to investment if SEO firms overinvest. To test this prediction, I need to estimate the likelihood of overinvestment. Overinvestment is defined as the investment in excess of the optimal investment. As a result, it is the difference between the observed investment and the optimal investment, provided that the difference is positive.

To estimate the optimal investment, I match each SEO firm to a nonissuing control firm on investment opportunity. The control firm is in the same industry as the SEO firm, is not financially constrained, and has the closest amount of investment opportunities as that of the SEO firm. The literature regarding investment suggests that investment opportunity and financial constraint are two important determinants of investment. ${ }^{9}$ I exclude potentially financially constrained firms from the matching pool of control firms so that the investment of these firms depends solely upon their investment opportunities. Financial slack is measured by the interest coverage ratio, which is earnings before interests and taxes divided by interest expense. I require control firm candidates to have an interest coverage ratio greater than three and above the first quartile in its

\footnotetext{
${ }^{9}$ The $q$-theory of investment implies that optimal investment is increasing a firm's investment opportunities and investment opportunity is the only factor that determines investment. Later studies (Fazzari, Hubbard, and Peterson, 1988; Hubbard, 1998) nevertheless reveal that the $q$-theory of investment fails to consider the effects of financing constraints on investment. In other words, $q$-theory only looks at the demand for investment but does not consider the supply of capital. If a firm has little internal capital and limited access to the capital markets, its observed investment will deviate from the optimal amount predicted by $q$-theory. These studies find supporting empirical evidence regarding the role of financing constraints in investment.
} 
industry (as classified by the two-digit SIC code). ${ }^{10}$ Following Smith and Watts (1992), investment opportunities are measured by the market-to-book value of assets $(V / A)$. Among the remaining pool, the control firm with the closest match on $V / A$ is chosen as the final matched firm. To ensure matching of high quality, I exclude $5 \%$ of the matched sample that has the largest differences in $V / A$ between the SEO firm and its control firm. ${ }^{11}$ The investment of the matched control firm is regarded as the benchmark of optimal investment for the SEO firm. I interchangeably refer to the difference between the investment of SEO firms and their control firm as benchmark-adjusted investment or abnormal investment.

In Panel B of Table V, I report the summary statistics of the benchmark-adjusted investment of SEO firms. The median is $8.24 \%$ of the issuer's book value of assets, or $4.07 \%$ of its market value. The mean values are again much higher than the medians. On average, SEO firms invest more than their control firms after the offering. In fact, about $67 \%$ of SEO firms invest more than their control firm (i.e., the estimated abnormal investment is positive). Only one-third of the SEO firms invest less than their control firms and the magnitude of "underinvestment" is small. This is also indicated by the positive skewness of abnormal investment.

Here, I note a caveat. SEO firms tend to be high-growth firms with many investment opportunities. One of the reasons for their offering of new equity is to raise investment capital. Since SEO firms are not a random sample, it is still possible that issuing firms optimally invest more than their control firms even if their market-to-book ratios are similar. In other words, the benchmark model of investment may not fully capture the optimal investment of SEO firms and the findings of positive abnormal investment do not necessarily mean that the firm is overinvesting. Considering this caveat, I do not argue that SEO firms overinvest simply based on the estimated mean and median abnormal investment, although they are positive and statistically significant. Instead, I focus my attention on the relative magnitude of abnormal investment across SEO firms. I assume that relative to firms with negative abnormal investment, firms with positive abnormal investment are more than likely overinvesting. Among firms with positive abnormal investment, I assume that firms with larger abnormal investment are more likely to overinvest. In order to detect whether some SEO firms overinvest, I examine the cross-sectional correlation between the postissue investment and the change in operating performance. The previous model predicts a positive association in firms with negative abnormal investment and a negative correlation in firms with positive abnormal investment. Findings of a negative relationship would support the overinvestment hypothesis.

\section{The Empirical Relationship between Investment and Firm Performance}

I examine the relationship between investment and firm performance first by decile analysis. I divide the sample of SEO firms into deciles based on the ranking of the postissue abnormal investment. Firms in the first (last) decile consist of the $10 \%$ of sample firms that have the lowest (highest) abnormal investments. Since about $34 \%$ of issuers invest less than their control firm, the firm with zero abnormal investment is in the fourth decile. Firms in the fifth to the tenth deciles invest more than their control firms and show positive benchmark-adjusted investment. Figure 2 illustrates the distribution of the median proceeds, raw investment (the observed

\footnotetext{
${ }^{10}$ Both conditions have to be satisfied to be in the matching candidate pool. Financial analysts usually view firms with an interest coverage ratio greater than three as financially strong firms. See the textbook by Stickney and Weil (2003, pp. 274-275). The ratio is often used to measure a firm's financial slack as in Bates (2005).

${ }^{11}$ People might argue that $V / A$ prior to the SEO is inflated by the temporary overvaluation of the stock and, therefore, does not necessarily capture true investment opportunities. If this is true, my matching tends to be conservative when labeling a firm as an overinvestment pursuer as I use an inflated measure of investment opportunity to find the control firm.
} 


\section{Figure 2. The Distribution of Seasoned Equity Offering (SEO) Proceeds and Subsequent Investment}

This figure illustrates the distribution of the median SEO proceeds, raw, and abnormal investment over SEO deciles. Variables are deflated by the book value of assets before the offering. The SEO sample is partitioned into deciles on the basis of the postissue abnormal investment. Firms in the first decile have the lowest abnormal investment and firms in the last decile have the highest abnormal investment.

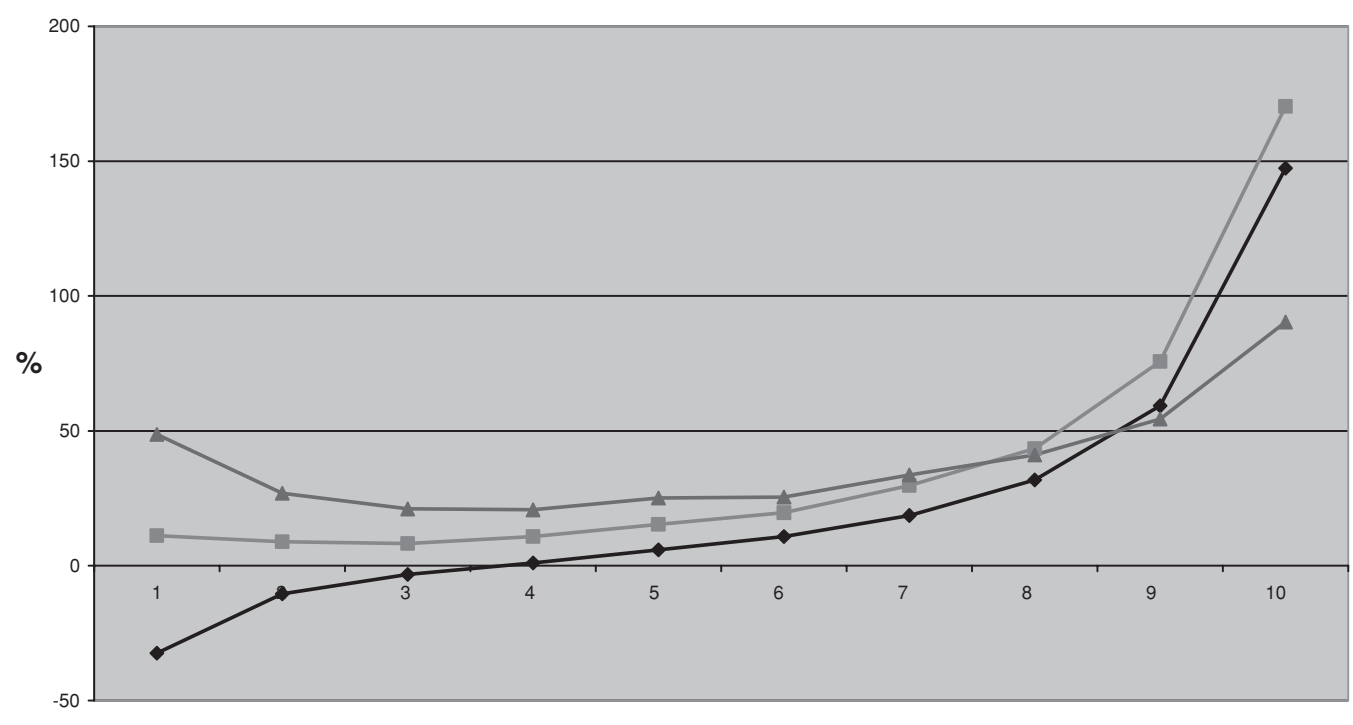

SEO Deciles Sorted by Abnormal Investment

Abn. $1 / \mathrm{A} \rightarrow-\mathrm{Raw} I / \mathrm{A} \rightarrow \mathrm{P} / \mathrm{A}$

investment), and abnormal investment over the SEO deciles. All the numbers are deflated by the book value of assets in the fiscal year prior to the offering. Note that the pattern of raw investment is very similar to that of the estimated abnormal investment. In fact, the cross-sectional correlation between the raw and abnormal investments is $81 \%$. This implies that the cross-sectional variation in abnormal investment is mainly driven by issuers' investment instead of the matching model. Firms that invest more after the offering tend to have higher abnormal investment. The curve of proceeds indicates an interesting convexity overinvestment deciles. In terms of magnitude, the median raw investment is lower than the proceeds in the first six deciles, is about the same in the following two deciles, and is much higher than the proceeds in the last two deciles.

After splitting the SEO sample into deciles, I compute the median changes in operating ROA and its two components, asset turnover and operating margin, on sales in each decile. Table VI presents the results and Figure 3 presents the graphic patterns. The correlation between the change in operating ROA and the abnormal investment roughly displays an inverse $U$ shape. The relation is positive in firms of the first four deciles, while the correlation is generally negative in the remaining firms. Note that firms in the first four deciles have relatively low abnormal investment. In fact, the abnormal investment of most of these firms is negative. Firms in the last six deciles have positive abnormal investment. Therefore, relative to the group of firms with negative abnormal investment, these firms are more likely involved in overinvestment. Consistent 
Table VI. Median Change in Operating Performance: Sorting Seasoned Equity Offering (SEO) Firms into Deciles by Benchmark-Adjusted Investment

The sample of SEO firms is divided into deciles on the basis of the benchmark-adjusted postissue investment. Firms in the first decile have the lowest abnormal investment while firms in the last decile have the highest abnormal investment. This table reports the median change in operating performance after the offering for each SEO decile. For each SEO firm, I compute the medians of operating performance in the preissue years and in the postissue years, respectively, and then calculate the difference between the pre- and the postissue performance. The reported numbers are the median difference across firms in each decile. The preissue years are defined to be the three years before the offering while the postissue years are the five years after the offering. If there are missing data, the median is computed using data for the remaining years. Figure 3 illustrates the graphic patterns of the changes.

\begin{tabular}{lcccr}
\hline \hline Investment Deciles & Operating ROA & Asset Turnover & $\begin{array}{c}\text { Operating Margin } \\
\text { on Sales }\end{array}$ & $\mathbf{N}$ \\
\hline 1 (low) & $-2.80^{* * *}$ & $-19.46^{* * *}$ & $-1.25^{* * *}$ & 244 \\
2 & $-2.78^{* * *}$ & $-10.94^{* * *}$ & $-1.00^{* * *}$ & 244 \\
3 & -2.12 & $-11.55^{* * *}$ & -0.12 & 244 \\
4 & -1.23 & $-14.26^{* * *}$ & 0.08 & 244 \\
5 & $-3.50^{* * *}$ & $-16.43^{* * *}$ & -0.53 & 243 \\
6 & $-2.41^{* * *}$ & $-19.22^{* * *}$ & 0.18 & 244 \\
7 & $-3.90^{* * *}$ & $-26.45^{* * *}$ & 0.16 & 244 \\
8 & $-3.83^{* * *}$ & $-27.32^{* * *}$ & 0.46 & 244 \\
9 & $-4.31^{* * *}$ & $-39.06^{* * *}$ & 1.09 & 244 \\
10 (high) & $-5.04^{* * *}$ & $-54.41^{* * *}$ & $1.75^{* * *}$ & 243 \\
\hline \hline
\end{tabular}

*** Significant at the 0.01 level.

with the prediction of the model, the cross-sectional association between investment and change in firm performance is positive if the likelihood of overinvestment is low, and is negative if the likelihood of overinvestment is high. The finding of negative correlation strongly supports the overinvestment hypothesis. When firms invest aggressively, their operating performance falls.

Change in asset turnover indicates a decreasing pattern over SEO investment deciles (i.e., asset productivity drops further if issuing firms overinvest to a greater extent. For firms in the decile of the highest abnormal investment, the drop in asset turnover is 54\%. Changes in operating margin on sales are negative and significant at the 5\% level only in the first two deciles, and are positive in the last five deciles. Thus, the performance deterioration of firms with positive abnormal investment is completely driven by the substantial drop in asset turnover. If managers squander capital in negative NPV projects, the average asset productivity will decline. Therefore, evidence that operating performance deterioration is accompanied by a drop in asset turnover lends support to the overinvestment hypothesis.

In order to check the robustness of the results, I partition the SEO sample into deciles based on the raw investment subsequent to the SEO. The purpose is to investigate whether the results are critically affected by the matching model of optimal investment. The results remain intact. I also use the univariate regression method to estimate the average change in operating performance. The results are qualitatively very similar. For firms that invest more than their control firm, I observe a significant deterioration in their operating performance. The deterioration can better be explained by the overinvestment hypothesis.

The inverse U-shape relationship between investment and the changes in operating performance suggests the importance of postissue investment when explaining performance deterioration. I 


\section{Figure 3. Median Change in Operating Performance of the Seasoned Equity} Offering (SEO) Investment Deciles

The following figures correspond to Table VI and display the median changes in operating ROA, asset turnover, and operating margin on sales in each SEO decile. Decile partitions are based on postissue abnormal investment. Firms in the first decile have the lowest abnormal investment and firms in the last decile have the highest abnormal investment.

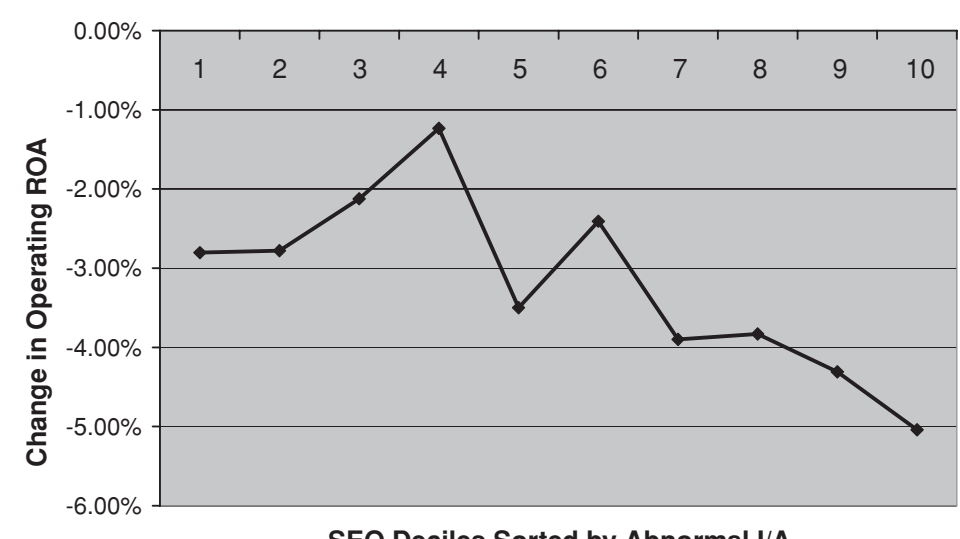

SEO Deciles Sorted by Abnormal I/A

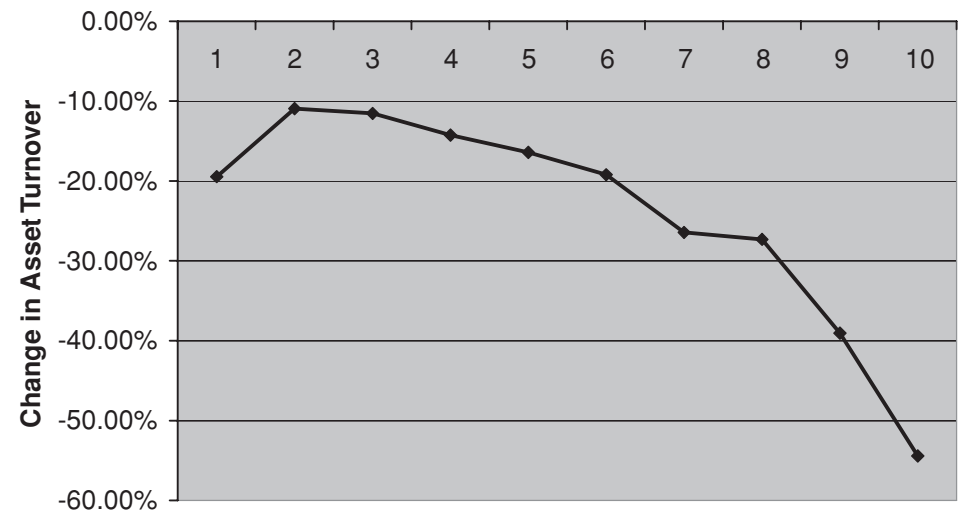

SEO Deciles Sorted by Abnormal I/A

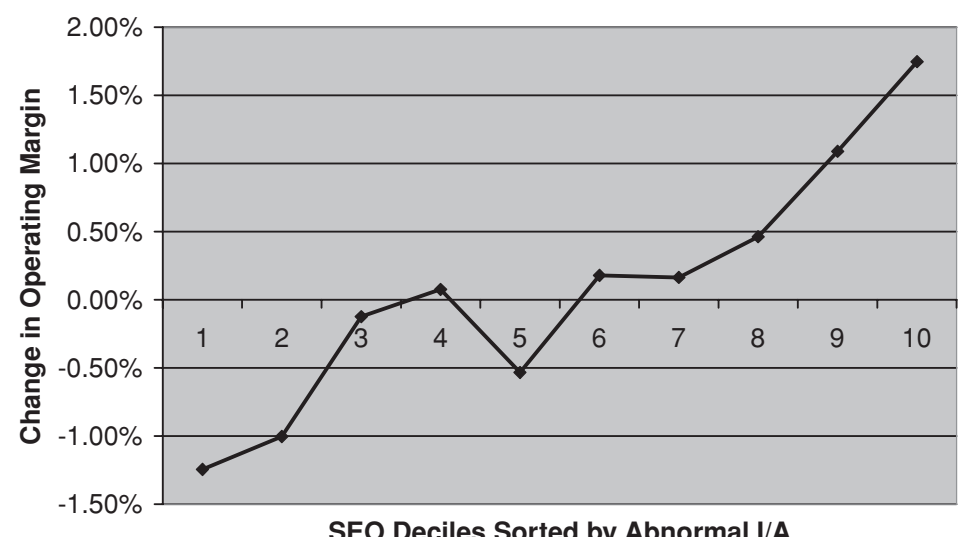

SEO Deciles Sorted by Abnormal I/A 
argue that the deterioration of firms with positive abnormal investment is mainly caused by managers' overinvestment. An alternative explanation is the lag effect of investment. Namely, investment increases operating assets immediately, but it may take years for the new operating assets to generate gains. The time lag between investment and the performance measured in this study is, on average, two years. ${ }^{12}$ I assume that most investment in positive NPV projects should generate operating income at an expected rate after two years. In case the gap of two years is not long enough, I check the robustness in various ways.

First, I estimate the postissue investment as the average of investments in Years 0 and 1, and the postissue performance as the median from Year 2 to Year 5. This procedure ensures no overlapping period between the investment and the performance measured and also increases the average gap between them. The results remain constant. Second, I investigate the operating performance from Year +6 to Year +10 for firms with positive abnormal investment. If the performance deterioration of these firms is caused by lag effects, I expect to observe a run-up in performance beyond five years after the offering. However, I do not find a significant reversal of performance from Year +6 to Year +10 . Additionally, I examine the relationship between abnormal investment and performance in a subsample of issuers with short operating cycles. The lag effects of investment should be less severe in these firms. The length of the operating cycle is measured as in Dechow (1994). ${ }^{13}$ However, I find that the negative effect of investment on firm performance in this subsample is as severe as that in the whole sample. Together, the evidence suggests that the negative association between investment and subsequent firm performance are unlikely caused by the lag effects of investment. Moreover, the lag effects of investment do not explain the positive link between investment and change in performance for firms that invest less than their control firm.

I examine nine years of operating performance surrounding SEOs, including three preissue years and five postissue years. The estimated performance changes are based on the median performance during the pre- and postissue years. To avoid the survivorship bias, I do not require firms to have all the nine years of performance data. I do not find a reason that this favors my results. However, I check the robustness by defining the pre- and postissue years differently. I define the pre- and postissue years, respectively, as the three years before and after the offering. Alternatively, I define the pre- and postissue years as the second and third years before and after the offering (by taking out the years immediately before and after the offering). None of these actions affects the main results.

In addition to the decile analysis, I also examine the relation between investment and firm performance by regression analysis. In order to avoid cross-correlations in the regression residuals, I employ the standard Fama and MacBeth (1973) regressions to control for any cross-correlation in residual errors. That is, the regressions are run for each year and the time-series mean and standard deviation of slopes are used to draw inferences. For instance, there are 65 SEOs in 1990. I run the regression of 1990 based on the variables of these 65 issuing firms. The dependent variable of the regressions is the postissue operating performance ( $R O A \_a$ ), measured as the median operating ROA during the postissue years (Year 1 to Year 5). Table VII reports the regression results. The model predicts that expected operating performance is positively related to investment if SEO firms do not overinvest. I test this hypothesis by the first regression model. Firms entering the first model have negative abnormal investment. In relation to other SEO firms, they are less likely

\footnotetext{
${ }^{12}$ I estimate the postissue investment as the average of Years 0,1 , and 2 . The postissue operating performance is measured up to Year 5.

${ }^{13}$ Operating cycle $=\left(\frac{\left(A R_{t}+A R_{t-1}\right) / 2}{\text { Sales } / 360}\right)+\left(\frac{\left(I n v_{t}+I n v_{t-1}\right) / 2}{\operatorname{COGS} / 360}\right)$, where $A R$ stands for accounts receivable, Inv stands for inventory, and COGS for cost of goods sold.
} 


\section{Table VII. Fama and MacBeth (1973) Regressions of Operating Performance}

This table presents the Fama and MacBeth (1973) regression results. The dependent variable $\left(R O A \_a\right)$ is the postissue operating ROA measured as the median operating ROA in the postissue years (Year 1 to Year $5)$. The independent variables are the postissue investment $[\operatorname{Ln}(I / A)]$, investment opportunities measured by $[\operatorname{Ln}(V / A)]$, offering proceeds deflated by firm value $[\operatorname{Ln}(P / V)]$, preissue operating ROA $\left(R O A \_b\right)$, firm size $[\operatorname{Ln}(A)]$, and a dummy variable of investment opportunities $(D u m)$. Dum equals one if $V / A$ is below the median and zero otherwise. Firms in the first regression invest less than their control firms (abnormal investment is negative). Firms in the second and third regressions invest more than their control firms (abnormal investment is positive). The regression of the fourth model applies to all firms. Regressions are run for each fiscal year in the period from 1980 to 1999. The table reports the means (across years) of the regression intercept and slopes. The $t$-statistics for the means, defined as the time-series mean divided by its standard error, are in parentheses. $N$ is the average number of observations in fiscal year regressions.

\begin{tabular}{|c|c|c|c|c|c|}
\hline ROA_a & I & II & III & ROA_a & IV \\
\hline $\operatorname{Ln}(I / A)$ & $\begin{array}{l}8.28^{* * *} \\
(3.17)\end{array}$ & $\begin{array}{l}-3.32^{* * *} \\
(-2.75)\end{array}$ & $\begin{array}{l}-2.30^{* * *} \\
(-2.71)\end{array}$ & $\operatorname{Ln}(P / V)$ & $\begin{array}{c}-1.34 \\
(-0.64)\end{array}$ \\
\hline $\operatorname{Ln}(V / A)$ & & $\begin{array}{l}11.05^{* * *} \\
(3.54)\end{array}$ & $\begin{array}{l}8.49^{* * *} \\
(3.06)\end{array}$ & $\operatorname{Ln}(V / A)$ & $\begin{array}{l}10.24^{* * *} \\
(3.73)\end{array}$ \\
\hline $\operatorname{Ln}(I / A)^{* * *}$ Dum & & & $\begin{array}{l}-2.29^{* * *} \\
(-2.62)\end{array}$ & $\operatorname{Ln}(P / V)^{* * *} D u m$ & $\begin{array}{l}-2.04^{* *} \\
(-2.15)\end{array}$ \\
\hline$R O A \_b$ & $\begin{array}{l}0.45^{* * *} \\
(6.69)\end{array}$ & $\begin{array}{l}0.32^{* * *} \\
(5.12)\end{array}$ & $\begin{array}{l}0.34^{* * *} \\
(6.54)\end{array}$ & $R O A \_b$ & $\begin{array}{l}0.41^{\text {*** }} \\
(9.33)\end{array}$ \\
\hline $\operatorname{Ln}(A)$ & $\begin{array}{l}4.11^{* * *} \\
(4.86)\end{array}$ & $\begin{array}{l}1.53^{* * *} \\
(3.72)\end{array}$ & $\begin{array}{l}1.40^{* * *} \\
(3.01)\end{array}$ & $\operatorname{Ln}(A)$ & $\begin{array}{l}3.33^{* * *} \\
(3.79)\end{array}$ \\
\hline Intercept & $\begin{array}{l}-37.83^{* * *} \\
(-3.77)\end{array}$ & $\begin{array}{c}-6.79 \\
(-1.07)\end{array}$ & $\begin{array}{l}-5.54 \\
(-1.08)\end{array}$ & Intercept & $\begin{array}{c}-10.83^{*} \\
(-1.87)\end{array}$ \\
\hline$N$ & 34 & 72 & 72 & $N$ & 106 \\
\hline
\end{tabular}

involved in overinvestment. The independent variables include the postissue investment deflated by book value of assets $[\operatorname{Ln}(I / A)]$, preissue operating performance measured by the median operating ROA during Year -1 to Year $-3\left(R O A \_b\right)$, and issuer firm size $[\operatorname{Ln}(A)]$. The regression results confirm the positive relationship between investments and expected operating performance when issuers are not overinvesting. The coefficient of investment is positive and significant at the $1 \%$ level ( 8.28 with a $t$-statistic of 3.17). Operating performance demonstrates some persistence, as reflected by the positive and significant coefficient of the preissue performance $(0.45$ with a $t$-statistic of 6.69). The average slope of firm size is significantly positive, implying that the deterioration in operating performance is less severe in larger firms than in smaller ones.

Excessive investment decreases firm performance and destroys value. The model also predicts that if managers overinvest after the SEO, the overinvestment can result in poorer operating performance. Testing this hypothesis, however, requires control for the optimal investment. Since optimal investment is a function of investment opportunity, I control for it by including the proxy for investment opportunity, $\operatorname{Ln}(V / A)$. The second and third regression models are designed to test this hypothesis. Firms entering these two regressions have positive abnormal investment. In relation to the firms in the first regression model, they are more likely to overinvest. The overinvestment hypothesis predicts a negative coefficient for the (excess) investment variable and a positive coefficient for the investment opportunity variable. I retrieve the predicted results. The average slope of investment is -3.32 with a $t$-stat of -2.75 . Controlling for investment opportunity, 
the post-SEO operating ROA is decreasing in investment. I obtain similar results if the investment variable is replaced by the estimated abnormal investment. The average slope of investment opportunity is 11.05 with a $t$-stat of 3.54 . SEO firms with relatively better investment opportunities yield better performance after the offering. Since the abundance of investment opportunity mitigates the free cash flow problem, this evidence also lends support to the overinvestment hypothesis. The slope of preissue performance is still positive and statistically significant. The magnitude is less than that of the first model $(0.32$ vs. 0.45$)$, suggesting that good pre-SEO performance persists less into the future for overinvesting firms.

In the third regression, I add an interaction variable, which is the product of the postissue investment $[\operatorname{Ln}(I / A)]$ and a dummy variable for investment opportunities (Dum). The dummy equals one if the market-to-book value of assets $(V / A)$ is below the median across firms and zero otherwise. Other explanatory variables are the same as in the second regression. Firms that enter the regression again have positive abnormal investment. The overinvestment hypothesis predicts that the coefficient of the interaction variable should be negative since, all else being equal, the negative effect of overinvestment on performance is more severe in firms with fewer investment opportunities. Supporting the overinvestment hypothesis, the average slope of this interaction variable is negative and statistically significant $(-2.29$ with a $t$-statistic of -2.62$)$. Overinvestment reduces operating performance more in firms with fewer investment opportunities.

In the last regression, I use SEO proceeds as an explanatory variable. In order to compare across firms, I deflate the proceeds by issuing the firm's market value prior to the offering. Similar to the third model, I employ an interaction variable of the proceeds and the investment opportunity dummy, and find that the average slope of the proceeds variable is negative though statistically not significant. The slope of the interaction variable is negative and statistically significant at the $1 \%$ level $(-2.04$ with a $t$-statistic of -2.15$)$. This suggests that for firms without abundant investment opportunities, more SEO proceeds exacerbate the free cash flow problem. The slope of investment opportunity and preissue performance remains positive and statistically significant.

The results from the Fama and MacBeth (1973) regressions are consistent with the findings from the decile analysis. Evidence suggests that managers' overinvestment does exist in some SEO firms and has significantly negative effects on the operating performance of these firms. The deterioration is more severe if issuing firms do not have abundant investment opportunities, but invest aggressively after the offering.

\section{Conclusions}

The operating performance of SEO firms decreases substantially after offerings. Meanwhile, the stock price performs poorly. What causes this disappointing performance? I propose managers' overinvestment as one explanation. A large amount of cash proceeds are at the discretion of managers after the equity offering increasing free cash flow problems. Subsequently, managers overinvest and firm performance deteriorates.

If managers invest to maximize firm value, I expect to observe a positive correlation between investment and future operating performance. Investment opportunities call for investment and optimal investment generates profit. The relation between investment and future operating performance, however, could be negative if a significant part of the investment is not used to increase firm value. Empirically, I document evidence that supports the existence of overinvestment. I find that the positive correlation between investment and subsequent operating performance exists only in firms that are not likely to overinvest. The relative likelihood of overinvestment is measured by the difference in investment between the SEO firm and its nonissuing control 
firm. The control firm is in the same industry as the SEO firm, is not financially constrained to invest, and has a similar amount of investment opportunities as the SEO firm. For SEO firms that invest more than their control firms, the postissue operating performance is negatively related to investment controlling for the optimal investment and preissue performance. This negative association stands in direct contrast to the prediction of the optimal investment model supporting the overinvestment hypothesis.

My paper contributes to the literature in the following ways. It points out that equity offerings and future operating performance are endogenously related and emphasizes the significant impact of postissue investment on firm performance. It provides to the literature a new explanation that aids in understanding postissue investment behavior and the poor operating and stock price performance of many SEO firms.

My findings suggest that managers of some firms can make use of the capital markets to generate free cash flow and then squander resources at the expense of shareholders. This challenges existing hypotheses that regard the acquisition and control markets as efficient monitors or a perfect control mechanism of free cash flow problems. For example, Easterbrook (1984) assumes that capital markets can monitor managers at low cost. Thus, it is beneficial to make the firm more dependent on (and, therefore, closely monitored by) capital markets suggesting this as one of the reasons why firms pay dividends. Dividend payouts disgorge the free cash flow under mangers' control and force the firm to visit capital markets frequently for investment capital. From the corporate control perspective, Jensen (1986) also suggests that capital markets are able to control agency costs of free cash flow. If managers of a firm squander capital in negative NPV projects, another firm will acquire the firm and increase its value by reallocating resources efficiently. In contrast, the findings of my study suggest that some managers make use of capital markets to generate free cash flow and then squander it at the expense of shareholders. The desirable monitoring of capital markets described by Easterbrook (1984) does not apply to a typical SEO firm. Most SEO firms neither pay dividends nor frequently issue equity. Although capital markets discourage seasoned equity offerings by lowering issuers' stock prices significantly at the announcement, offerings by firms with few investment opportunities are not prevented. The corporate control function of capital markets does not work well for SEO firms either. Prior studies suggest that SEO firms are overpriced for a long time after the offering. Control markets cannot solve the overinvestment problem as no rational bidder has an incentive to buy an overvalued firm (Jensen, 2005). This study implies that the ability of capital acquisitions and control markets to prevent overinvestment by SEO firms is rather limited. Other mechanisms, such as reinforcement of corporate governance and better contracts to align the interests of different parties, are still needed.

\section{References}

Abel, A.B., 1983, “Optimal Investment under Uncertainty,” American Economic Review 73, 228-233.

Abel, A.B. and O.J. Blanchard, 1983, “An Intertemporal Model of Saving and Investment," Econometrica 51, 675-692.

Barber, B.M. and J.D. Lyon, 1996, "Detecting Abnormal Operating Performance: The Empirical Power and Specification of Test Statistics," Journal of Financial Economics 41, 359-399.

Barclay, M.J., F. Fu, and C.W. Smith, 2009, "Strategic Financial Management: Evidence from Seasoned Equity Offerings," University of Rochester Working Paper. 
Bates, T.W., 2005, “Asset Sales, Investment Opportunities, and the Use of Proceeds," Journal of Finance $60,105-135$.

Blanchard, O.J., F. López-de-Silanes, and A. Shleifer, 1994, "What Do Firms Do with Cash Windfalls?" Journal of Financial Economics 36, 337-360.

Brous, P.A., V. Datar, and O. Kini, 2001, "Is the Market Optimistic about the Future Earnings of Seasoned Equity Offering Firms?” Journal of Financial and Quantitative Analysis 36, 141-168.

Dechow, P., 1994, “Accounting Earnings and Cash Flows as Measures of Firm Performance: The Role of Accounting Accruals," Journal of Accounting and Economics 18, 3-42.

Denis, D.J. and A. Sarin, 2001, "Is the Market Surprised by Poor Earnings Realizations Following Seasoned Equity Offerings?” Journal of Financial and Quantitative Analysis 36, 169-193.

Easterbrook, F.H., 1984, “Two Agency-Cost Explanations of Dividends," American Economic Review 74, 650-659.

Fama, E.F. and J.D. MacBeth, 1973, “Risk, Return, and Equilibrium: Empirical Tests,” Journal of Political Economy 81, 607-636.

Fazzari, S.M., R.G. Hubbard, and B.C. Peterson, 1988, "Financing Constraints and Corporate Investments," Brookings Papers on Economic Activity 1, 141-195.

Hansen, R.S. and C. Crutchley, 1990, “Corporate Earnings and Financings: An Empirical Analysis,” Journal of Business 63, 347-371.

Healy, P.M. and K.G. Palepu, 1990, "Earnings and Risk Changes Surrounding Primary Stock Offers," Journal of Accounting Research 28, 25-48.

Healy, P.M., K.G. Palepu, and R. Ruback, 1992, "Does Corporate Performance Improve after Mergers?” Journal of Financial Economics 31, 135-175.

Hubbard, R.G., 1998, “Capital-Market Imperfections and Investments,” Journal of Economic Literature 36, 193-225.

Jegadeesh, N., 2000, "Long-Term Performance of Seasoned Equity Offerings: Benchmark Errors and Biases in Expectations," Financial Management 29, 5-30.

Jensen, M.C., 1986, “Agency Costs of Free Cash Flow, Corporate Finance and Takeovers," American Economic Review 76, 323-329.

Jensen, M.C., 1993, “The Modern Industrial Revolution, Exit, and the Failure of Internal Control Systems," Journal of Finance 48, 831-880.

Jensen, M.C., 2005, “Agency Costs of Overvalued Equity,” Financial Management 34, 5-19.

Jung, K., Y. Kim, and R.M. Stulz, 1996, “Timing, Investment Opportunities, Managerial Discretion, and the Security Issue Decision,” Journal of Financial Economics 42, 159-185.

Lang, L., A. Poulsen, and R. Stulz, 1994, “Asset Sales, Firm Performance and the Agency Costs of Managerial Discretion," Journal of Financial Economics 37, 3-37.

Lang, H.P.L., R.M. Stulz, and R.A. Walkling, 1991, “A Test of the Free Cash Flow Hypothesis: The Case of Bidder Returns,” Journal of Financial Economics 29, 315-335.

Lee, I., 1997, “Do Firms Knowingly Sell Overvalued Equity?” Journal of Finance 52, 1439-1466.

Loughran, T. and J.R. Ritter, 1995, “The New Issue Puzzle,” Journal of Finance 50, 23-51. 
Loughran, T. and J.R. Ritter, 1997, "The Operating Performance of Firms Conducting Seasoned Equity Offerings," Journal of Finance 52, 1823-1850.

Loughran, T. and J.R. Ritter, 2000, "Uniformly Least Powerful Tests of Market Efficiency," Journal of Financial Economics 55, 361-389.

Lyandres, E., L. Sun, and L. Zhang, 2008, "The New Issue Puzzle: Testing the Investment-Based Explanation," Review of Financial Studies 21, 2825-2855.

Nohel, T. and V. Tarhan, 1998, "Share Repurchases and Firm Performance: New Evidence on the Agency Costs of Free Cash Flow," Journal of Financial Economics 49, 187-222.

Rangan, S., 1998, "Earnings Management and the Performance of Seasoned Equity Offerings," Journal of Financial Economics 50, 101-122.

Ritter, J.R., 2003, "Investment Banking and Securities Issuance," in G. Constantinides, M. Harris, and R. Stulz, Eds., Handbook of the Economics of Finance, Amsterdam, Elsevier Science.

Shivakumar, L., 2000, "Do Firms Mislead Investors by Overstating Earnings before Seasoned Equity Offerings?" Journal of Accounting and Economics 29, 339-371.

Smith, C.W., Jr., 1986, "Investment Banking and the Capital Acquisition Process," Journal of Financial Economics 15, 3-29.

Smith, C.W. and R.L. Watts, 1992, "The Investment Opportunity Set and Corporate Financing, Dividend and Compensation Policies," Journal of Financial Economics 32, 263-292.

Spiess, D. K. and J. Affleck-Graves, 1995, "Underperformance in Long-Run Stock Returns Following Seasoned Equity Offerings," Journal of Financial Economics 38, 243-267.

Stickney, C.P. and R.L. Weil, 2003, Financial Accounting: An Introduction to Concepts, Methods, and Uses, 10th Ed., Carlsbad, CA: South-Western Press.

Teoh, S.H., I. Welch, and T.J. Wong, 1998, "Earnings Management and the Underperformance of Seasoned Equity Offerings," Journal of Financial Economics 50, 63-99.

Tobin, J., 1969, "A General Equilibrium Approach to Monetary Theory," Journal of Money Credit and Banking 1, 15-29. 